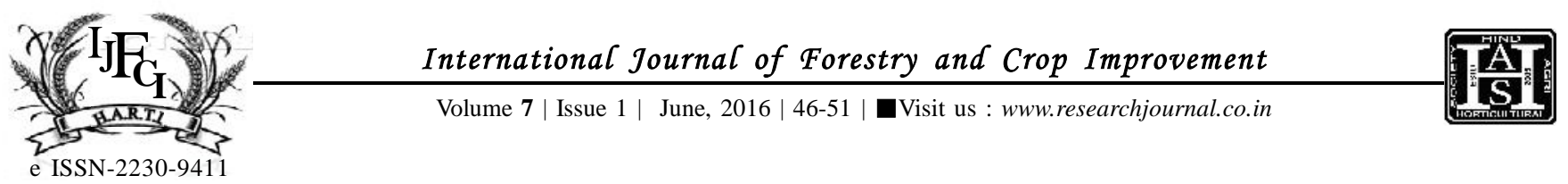

\title{
Hydro geochemical analysis and evaluation of ground water quality of Perur taluk, Coimbatore
}

\author{
S. Shalini, G. GeEthamalika and M. Prasanthrajan
}

\begin{abstract}
An attempt has been made to know the quality and hydro geochemistry of ground water in the Perur taluk of Coimbatore district and to check whether the water contains arsenic. Ground water samples were collected from twenty four villages in Perur taluk. In each village two samples were collected from two different bore wells. The water samples were collected from the bore wells with the depth range from $200 \mathrm{ft}$ to $800 \mathrm{ft}$. Chemical parameters namely, pH, electrical conductivity (EC), total dissolved solids (TDS), chlorides, hardness, iron, phosphates, nitrates, sulphates and arsenic were analyzed using standard protocol. The results were compared with water quality standards given by World Health Organization (WHO). The ground waters of eight locations namely Sundakkamuthur, Vedapatti, Komarapalayam, Madvarayapuram, Veera Keralam, Jagirnaicken palayam, Puluvapatti and Vadavalli are well within the water quality standards for drinking and irrigation purpose. Whereas the ground waters of remaining sixteen locations of Perur are not suitable for drinking but it can be used for irrigation purpose. With respect to arsenic poisoning, ground water samples of all the twenty four locations of Perur are well within the permissible limit.
\end{abstract}

KEY WORDS : Ground water, Hydro geochemistry, Arsenic, Water quality

How TO CITE THIS ARTICLE : Shalini, S., Geethamalika, G. and Prasanthrajan, M. (2016). Hydro geochemical analysis and evaluation of ground water quality of Perur taluk, Coimbatore. Internat. J. Forestry \& Crop Improv., 7 (1) : 46-51, DOI: 10.15740/HAS/IJFCI/7.1/46-51.

Article Chronical : Received : 24.12.2015; Revised : 11.04.2016; Accepted : 12.05.2016

\section{MEMBERS OF RESEARCH FORUM}

Address of the Correspondence : S. SHALINI, Department of Chemistry, Nirmala College for Women, Autonomous Institution, COIMBATORE (T.N.) INDIA Email: shaliniprasanthrajan@gmail.com

Address of the Coopted Authors : G. GEETHAMALIKA, Nirmala College for Women, Autonomous Institution, COIMBATORE (T.N.) INDIA

$\overline{\text { M. PRASANTHRAJAN, Agricultural Research Station, Virinjipuram, VELLORE (T.N.) }}$ INDIA 